\title{
A Comparative Study of Saraiki Animal Tales with the American
} Animal Tales

\author{
Zahoor Hussain $^{1} \&$ Saiqa Imtiaz Asif ${ }^{2}$ \\ ${ }^{1}$ Ph.D. Scholar, Department of English, Bahauddin Zakaryia University, Multan, Pakistan \\ ${ }^{2}$ Professor of English, Department of English, Bahauddin Zakaryia University, Multan, Pakistan \\ Correspondence: Zahoor Hussain, Ph.D. Scholar, Department of English, Bahauddin Zakaryia University, \\ Multan, Pakistan. E-mail: zahoor_linguist@bzu.edu.pk
}

Received: May 21, 2019 Accepted: August 19, 2019 Online Published: September 6, 2019

doi:10.5539/ijel.v9n5p307 URL: https://doi.org/10.5539/ijel.v9n5p307

\begin{abstract}
Recently, the researchers and scholars have developed a tradition of reviving past and fostering nationalism among the speakers through their past/history. Saraiki civilization has also its both tangible and intangible assets like other oldest rural civilizations of the world. There at international level, a lot of work has been done in the field of folktales so far as their classification according to their types structures and functions. In Pakistan, no significant work has been done. The study is aimed to compare the Saraiki animal tales with the American animal tales through the American model developed by Uther in 2004 popularly known as Aarne-Thompson-Uther model. The current study is the comparative structural analysis of the Saraiki folktales. The Saraiki folktales were collected through participant observation, observation and interviews. The study was conducted in the rural areas of Southern Punjab, Pakistan. The multistage approach was applied to collect the folktales from the research area on the principle of probability sampling through the informants from the study area. The researcher for this purpose used the purposive sampling technique to select the informants of his study Saraiki folktales. The researcher selected 09 animal tales were compared to the plots recorded in an international American Arne-Thompson-Uther (2004) model generally known as the ATU and traced similarities of plots between the Saraiki folktales and internationally recorded American animal tales. The Saraiki oral tradition may be collected and classified for the preservation of cultural heritage and for further research in this field.
\end{abstract}

Keywords: Saraiki rural area, Saraiki culture, folktale, cultural heritage, Saraiki region, Geo-historic method, Aarne-Thompson-Uther ATU system of classification

\section{Introduction}

The tradition of folktales started from centuries unknown when human beings started conceptualizing the universe, nature and the divine aspects of human life. For this purpose, the tool of narrative was adopted by the ancestors. So, in the narratives, the myths and legends along with the exponents of divine were formulated. The ancestors of the human beings portrayed and positioned themselves in the narratives of the past i.e., folktales through the help of their imagination in a way they wanted to see themselves. Their observations, experiences and epitomes of lives and what else they wanted and wished were presented in the construct of their narratives. With the passage of time, myths and legends took the forms of folktales (Zipes, 1983; 1996; 2001). According to Zipes (1996), these folktales were transferred by word of mouth from generation to generation into different forms such as animal tales, fairytales, parables, ballads and fables. This tradition was esteemed in the olden days and societies:

Telling tales, using words and symbols, endowed the speaker with authority and power. A magic folktale did not only concern the miraculous turn of events in the story, but also the magic play of words by the teller as performer (p. 2).

Furthermore, folktales also facilitate people to look deep at their own cultures (Alembi, 1999). Wakituki (1999) describes folktales as efficient teaching systems which frame one's identity and foster creativity. He furthers his stance by saying that changing times and different contexts in which they are told have impact on folktales. The study of folklore has been established as a genre because of its differences: structural and typological. The word genre has been derived from the French language which stands for kind/type or class. This term has been used in 
different disciplines including linguistics. This word stands for a particular type of text with certain different conventions and patterns with the motives of communication behind it and these patterns are recognized by the linguists and academic community (Swales, 1990). The concept of genre has been useful for the researchers as with the help of this notion; the texts can be grouped on the basis of certain structural, thematic and other similarities. In this regard, the method of classification coined by Aarne-Thompson with the latest edition and amendments by Uther called the Aarne-Thompson-Uther ATU (2004) is an attempt to establish the types of folktales on the basis of similarities and frequency of their occurrences at different places and spaces in the word. The motifs across the folktales can be traced down on the principles of similarities. Propp (1928/1968) did his seminal work titled "The Morphology of Folktale". He found the commonly occurring 31 functions among the Russian fairy tales.

At the same time, the researchers have shown keen interest to study these tales. The researchers and linguists have read and re-read them in order to trace certain new propensities among them (summers, 1990). Some of the researchers have studied them from the psychological perspectives (Snider, 2009); others have taken into consideration the socio-cultural conditions in mind (Killeen, 2009), yet another group of linguists have studied from the religious aspects of their nations (Quintus, 1991). Some of them have studied the fairy tales in order to find the generic structure among them (Rahman, 2011). This study focused on tracing the history of the Saraiki folktales by identifying their types through comparing the plots of the Saraiki folktales with the plots given in the latest edition of the Aarne-Thompson-Uther (2004) system of classification. The current study will help find/add variants of the types of the ATU through the similarities of plots of the Saraiki folktales with the ATU folktales.

The history of Saraiki people dates back to the Hakra and Indus civilizations nearly about 5000 years ago. Both these civilizations were considered well developed in almost all walks of life. The people of these civilizations were considered well acquainted with the written symbols as it has been proven by the seals and stamps found in Jalil Pura, Harapa and Multan through excavations. Unfortunately, these civilizations were destroyed by epidemics, severe changes in the climate and heavy floods nearly about 5000 B.C. (Akbar, 2012). After some time, there entered the Aryans around 1000 to 2000 B.C. The Aryans arrived from the central Asia and after entering the sub-continent were divided into two groups. One group moved towards the Ganges valley and the other group was settled in the Indus valley - the land of Sapta-Sindhu. The area of the Saraiki speaking community lies in the center of Pakistan on both sides of the Indus nearly $28 \mathrm{~N}$ to $33 \mathrm{~N}$ along with the lower ranges of the Sutlej and Chenab. Before the partition, the Saraiki speaking community was also settled across the border and still many speakers of this language are in the adjacent areas of India on the either sides of the political borders. The major neighboring languages of the Saraiki language are Pashto, Northern Lahnda, Punjabi to the north-west and to the south Sindhi (Shackle, 1976). Shackle (1976) gave a map to demonstrate the adjoining areas of the Saraiki region. 


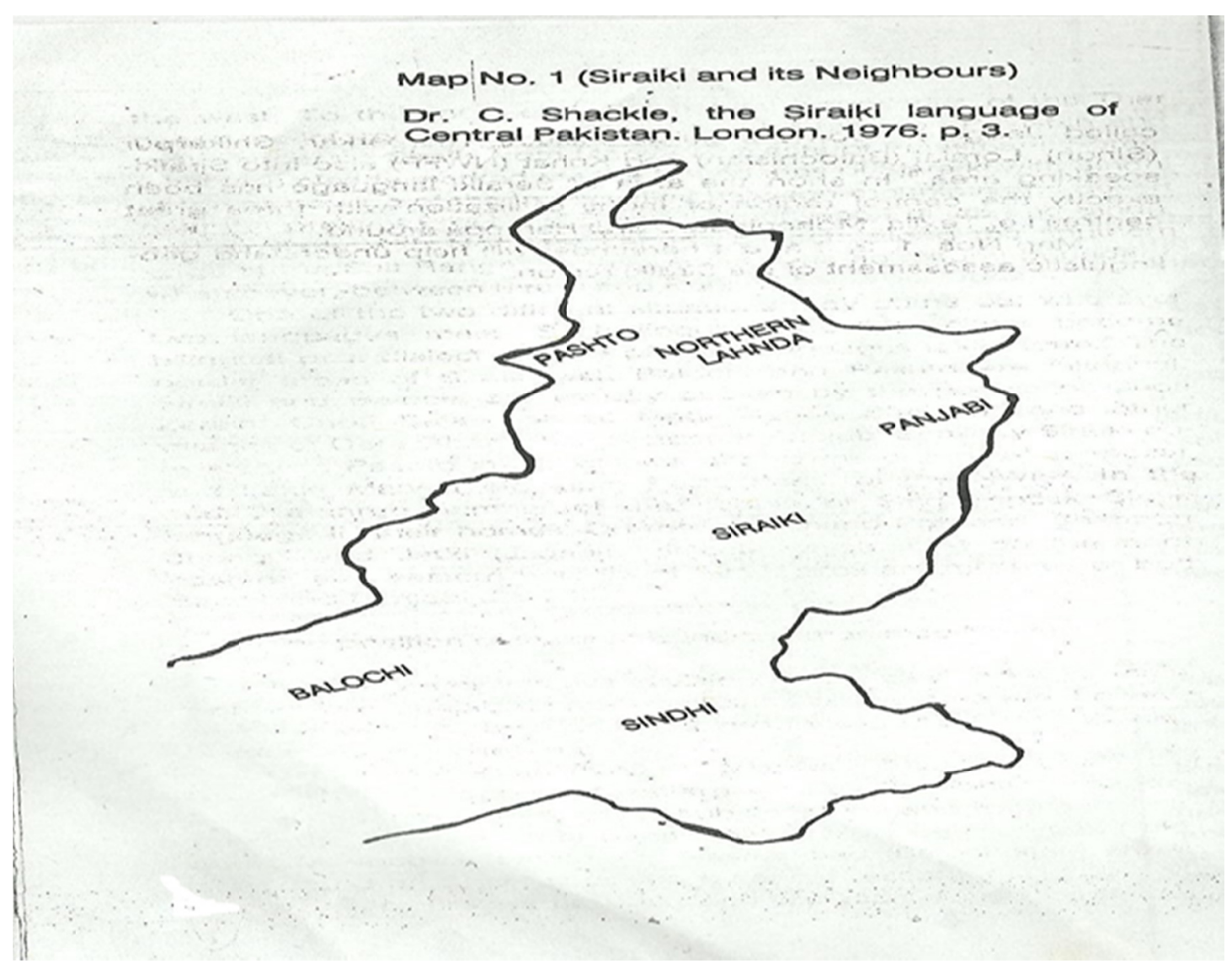

Figure 1. Map of the Saraiki region proposed by Shackle in 1976

The Saraiki region comprises a large area of the Punjab along with the three divisions of the Punjab, Multan Division, Dera Ghazi Division and Bahawalpur Divisions. However, some districts of afore- mentioned divisions do not have a large number of the Saraiki speaking people. The following districts of the Bahawalpur Division have a large number of the Saraiki speakers, District Bahawalpur, District Rahim Yaar Khan, and District Lodhran. Similarly, nearly all districts of Dera Ghazi Khan have a large number of the Saraiki speakers i.e. District Dera Ghazi Khan, District Muzaffar Garh, District Layyah and District Rajan Pur. Multan division has also a large number of the Saraiki speakers as Multan has been the center of the Saraiki culture, language and oldest city in the subcontinent. The map of Punjab is given below: 


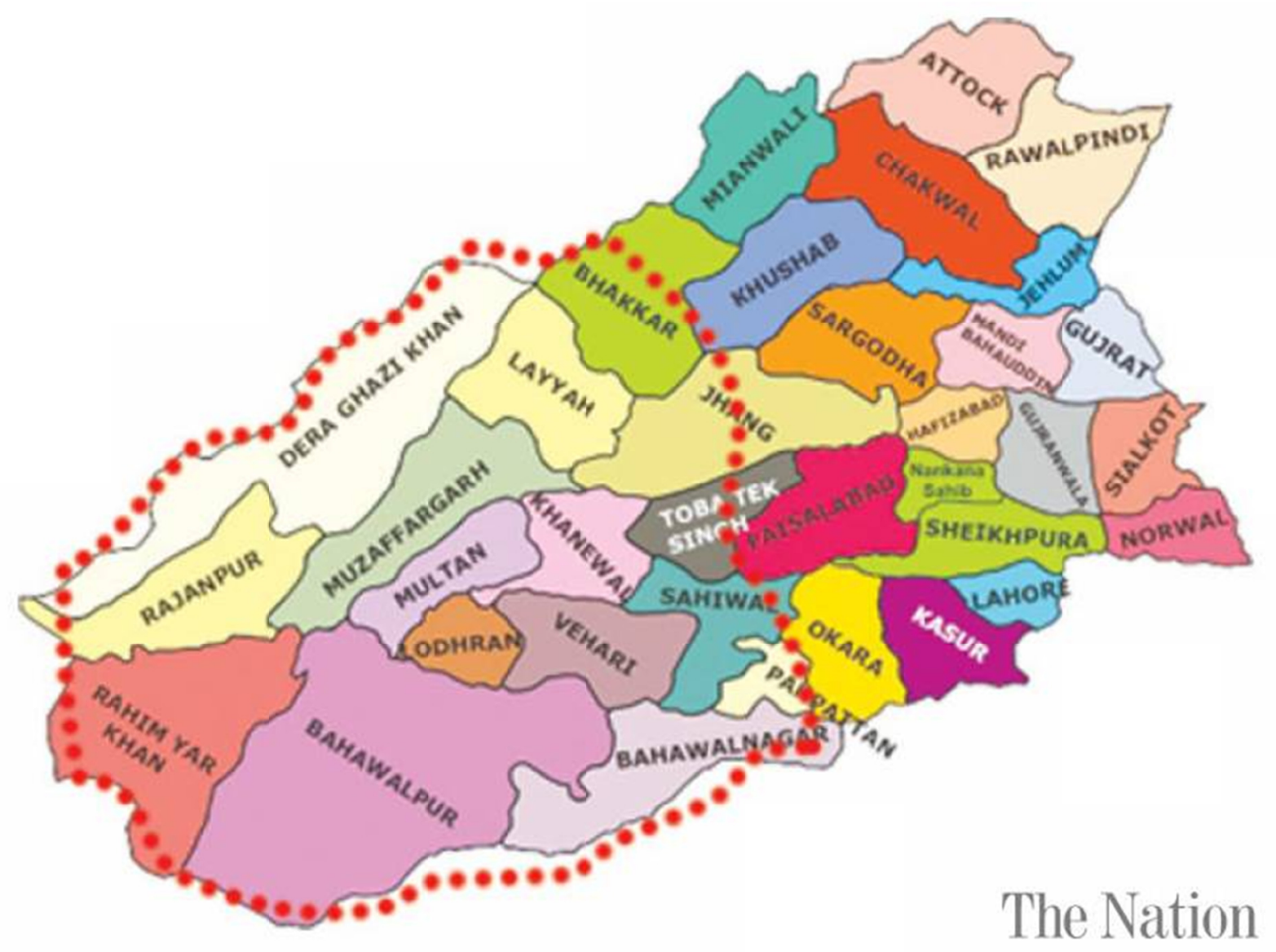

Figure 2. Map of Punjab

Note. Retrieved from www.google.com.pk.

\section{Literature Review}

The term folktale nearly covers all forms of oral traditional narratives however; folktales are different from the legends because they are usually based on the facts. All other traditional forms of narratives are covered by this umbrella term such as fairy tales or wonder or magic tales, animal tales, jokes and anecdotes, etiologic tales, tall tales, and religious tales. Folktale in the German language is termed as 'Marchen', in the French language 'Cante popu-laure' and in English the term is equal to a 'fairy or household tale' while Marchen is a long tale comprising motifs and episodes. The often-quoted examples of folktales in English are, "Cinderella, Snow White, Hansel and Gretel" (Thompson, 1946). Thompson (1946) also gave the difference between myth, sage and Marchen (folktale). According to him, myth is associated with philosophy that tells in detail about life, death, gods, cults, fate and nature. Sage is about ancient historical perspective and it has the touch of both love and hate. Sage is usually transferred unconsciously from one generation to the next one. And Marchen or folktales were used to entertain people. There are many types of the folktale such as the fairy tales, humorous tales, animal tales, formula tales and novella. Sometimes, it is very tough to draw a line between the animal and human tales because both the animal and human beings exist in certain tales, however; the tales with animals as the chief and main characters are called animal tales. All over the world, different animals have different characteristics such as Thompson in his book; 'The Folktale' labels the characteristics of the bear, fox and rabbit as, "Thus the bear is stupid, the fox sly, the rabbit swift and willy" (Thompson, 1946, p. 217).

Green (2009) enlisted different types of the American folktales including animal tales. He gave the following categories of the American folktales: tales of origins, tales of conflict and society, tales of the supernatural and tales of animals. Animal tales have animals as heroes, heroines, protagonists, adversaries, donors and helpers. These animals are often speaking animals such as speaking birds and jackals. Green furthered his point of view that even the tales of human origins have animals as protagonists. In an American folktale, 'Raven Befriends the Human Race' Raven performs an important role by introducing human species on the earth and also considered 
one of the birds from the mythology of aboriginals in Native America. Similarly, another Native American animal tale, 'The Youth Who Joined the Deer' presents an intimate relationship between the humans and animals even after life hereafter. Some of the Native American animal tales have the Indian characters for instance, the American tale, 'Tijarha the Sorcerer' has Tajiarha - an Indian character, A missionary preaches them and offers Christianity in place of their local animist beliefs, they resist as: "We have many friends among the creatures about us. Some of us have snake friends, some eagles, some bears, and the like how can we desert our friends" (Green, 2009, p. 47).

Works on Saraiki folk lore were also done by the local scholars and writers as in this regard two important books were published. In 2000, Shah brought forth a book 'Kareenha Da Phol' on Saraiki folk tales with three most renowned tales of Saraiki region. Mughal (2004) in his book 'Alf Bay Batooa' included 39 folktales of Saraiki area. Ayyaz (2004) wrote a book 'Saraiki Watare' on the style and importance of Saraiki folk literature. The Daily Khabrain newspaper of Multan center in its weekly edition Waseeb Sung also published Saraiki folk tales like 'Choran Kon Poven Mor', 'Mohanat Ap Danawat', and 'Khote Te Ghore Hik Mul' in 2004. Yad (2004) presented a research report 'Lok Qissae Da Pandh' in the Saraiki Magazine 'Jevan Jog'. In 2005, Awan wrote Saraiki folktales in an interesting style and way in his book 'Wade Lok Wadyian Ghaleen'. This book is replete with many didactic lessons hidden in all the folk tales. Shah (2008) presented his book 'Sojhal Qissae' with dozens of folk tales of Saraiki area. Khadeeja (2008) also compiled Saraiki folk tales in her book 'Saraiki Dharti De Qissae'. Rasool (2008) in the second part of his book 'Nitare' discussed in full length the nature and importance of Saraiki folk tales. Mughal (2008) also discussed and described the tradition of Saraiki folk tales. Further; he also brought forth the issue of gender in Saraiki folk tales in his book 'Pachera'. Naich (2010) recorded and compiled Saraiki folk tales from the desert area of Bahawalpur division Cholistan. Ashraf's (2011) book on Saraiki folktales 'Allah Ap Badshah Hae' was published. Same year another important book on Saraiki folktales was compiled by Ghani.

In order to trace the history and origin of folktales, the comparative approach and historic-geographic or the Finnish method was used by the folklorists, linguists and the researchers. Aarne developed their system of classification based on the above stated approach and method in 1912 and later that system of classification was modified many times by many researchers such as Thompson, and Uther and its recent classification under the title Aarne-Thompson-Uther: The Types of International Tale published by Uther along with his colleague in 2004. A lot of studies were also conducted in the subcontinent on the folktales to know various aspects in them and mostly the initial studies were collections of folktales from the different regions of the Indian subcontinent. Temple (1884) observed the plot structure of the Punjabi Folktales and found a near similarity between the plots of the Punjabi folktales and the bardic poems (quoted by Haase, 2008). Hinton (1887) collected the Kashmiri folktales primarily with the intention of learning the Kashmiri language and secondly to know the belief system of the local community (quoted by Haase, 2008). Another study was done by Kincaid (1914) from Deccan. He collected the folktales from Deccan and compiled them under the title, 'Deccan Nursery Tales or Fairy Tales from the South'. In his study, he confirmed the concept of supernatural helper and aid. Rahman (1968) completed his study on the Folktales of Swat and he found in them the dominant character of "Pari" fairies. The home of fairies is considered the Karakoram area (Pakistan) and the word for Fairy in the subcontinent is, "Pari" that is an equal cognate of the English word, 'fairy'. Wolf (1990) conducted the study on the presence of "Pari" in the Yasin Valley (Ishkoman) in Pakistan. She found through her ethnographic study that the people of the valley had beliefs about the presence of fairies in the valley (quoted by Haase, 2008).

The comparative and structural approaches stated ahead have drawn their insight from linguistics as their techniques and methods are based on linguistic insights. Recently, linguistic perspectives and methods are also used in the classic fairy tales to find relationship between language and gender such as "Little Red Riding Hood" (Alessandra, 2004). These comparative approaches created a group of linguists and researchers who drew on historic-geographic method. The motive of aforementioned group of folklorists and linguists was to find out tale types cross-culturally from the folktales collected through both written and oral sources. The origin of this method could be traced in 19th century linguistics and philological criticism of text. Linguists firstly discovered the familial relations of different languages in the world and how these familial relations developed over a period of time (Haase, 2008). In fact, this method revolves around the monogenesis theory of folklore i.e., that there is Ur-form of all folkloric items which spread all over the world, however at local places, these variants of Ur-form have accepted certain cultural contexts and have variations in them. Ur-form is a German word used by Krohn in order to find original form of the folk songs in his work Kalevala. Julias Krohn was a philologist who tried it in folklore (quoted by Haase, 2008). No doubt, this idea came from the mythological approaches which were directed to find the Ur-form or original form of the text. The word Ur-form means an archetypal form and this 
idea was also exploited by Krohn (1971) in his doctoral thesis to analyze animal tales.

\section{Methodology}

The researcher employed Aarne, Thompson and Uther (2004) classificatory method popularly known as the ATU. The classification system was initially made by the different folklorists, however; it was a Finnish folklorist Aarne who developed his system of classification on the basis of Finnish, Danish and German folktales (Aarne, 1912). The system of classification was divided into the following categories: (i) Animal tales (No. 1299), (ii) Ordinary tales (No. 300-1199) and (ii) Anecdotes and jests (No. 1200-1999).The second edition of Aarne system of classification has further sub divisions which include the following: A. Tales of Magic, B. Religious Tales, C. Novella or Romantic tales, and D. Tales of the Stupid Ogre. Similarly, the sub division A. Tales of Magic has further forms for instance: a. Supernatural Adversaries b. Supernatural or Chanted Husbands c. Super Human Tasks d. Supernatural Helpers e. Supernatural Objects f. Supernatural power. Uther along with his editorial team such as Dinslage, Fahrmann, Goldberg and Schmibbie worked collaboratively on the system of classification and developed the latest system of classification was developed by the American scholar called Antti-Thompson-Uther (ATU) system of classification (Uther, 2004). The classification system (ATU) was made more wide spread and popular by the incorporation of research in it from all over the world. Similarly, many explanatory notes were added in order to exemplify the details which were missing in the previous systems of classification.

The data were collected from district Multan. One of the important tasks was the selection of the informants from the study area, Multan. The researcher for this purpose used the purposive sampling technique to select the informants of his study Saraiki folktales. In fact, by the use of purposive sampling, the researcher got the chance to approach and select the right informants for the study. The researcher being the native speaker of Saraiki was familiar with the tradition of story-telling. The researcher collected information about the informants both females and males. The researcher selected 7 informants from the rural areas of Southern Punjab, Pakistan. The researcher in person met and attended all the sessions into collect data for his study. The researcher was helped by his relatives, family members, colleagues, students and their close relatives. The researcher made a plan to visit different informants at different times usually during evening times as they were free and relaxed to share their experience of storytelling. The researcher and the informants were the native speakers of Saraiki language that was why both the researcher and the informants were familiar with this tradition of storytelling. The process of collecting folktales went smoothly and in congenial atmosphere. The most senior informants were however a bit hesitant before the tape recorder, and the researcher tried his level best to relax them and adjusted the recorder in such a way that they should feel easy and comfortable. The researcher audio taped all the folktales from the informants with their due and prior permission. There were 2 sessions of different duration. The researcher codified the audio tapes according to sessions of storytelling.

\section{Data Analysis}

The researcher after collecting the folktales from the informants started the procedure of analyzing the data. The researchers listened to the recorded folktales carefully. The researcher selected them for analysis according to the objectives of the study. The researcher for the true apprehension of the folktales for the purpose of research after reading and rereading constructed the plot of the selected folktales. In the formation of the plots, all type of necessary information along with the line of action and abrupt changes, climaxes and anticlimaxes were observed strictly by the researcher. The plots of the folktales were drawn in English by the researcher himself. The data that was naturally recorded was revisited by the researcher. The researcher as being the native speaker of the Saraiki language followed the main points in the plot construction. The researcher after the formulation of the plots of the selected folktales for the study determined the types of the Saraiki folktales through the application of geo-historic method.

After the construction of plots of folktales selected for the study, the researcher determined the tale types through structural comparative approach. The researcher read and re- read the selected folktales many times before determining the tales' types through the ATU (2004) Typology. At the first stage, the researcher identified the major categories of the Saraiki folktales such as animal tales, jokes and anecdotes, fairy tales and religious tales. Then, the researcher after the thorough examination of the plots of folktales compared them with the plots recorded internationally in the ATU (2004) manual. The researcher matched them with the Aarne-Thomson-Uther Typology ATU (2004) and enlisted the Saraiki folktales on the basis of the similarities of the plots between them. The comparison is given in Table 1: 
Table 1. Comparison of Saraiki Animal Folktales with the ATU Animal Folktales

\begin{tabular}{|c|c|c|c|}
\hline $\begin{array}{l}\text { Title of } \\
\text { Folktale }\end{array}$ & Plots of ATU Folktales & Plots of Saraiki Folktales & $\begin{array}{l}\text { Proposed } \\
\text { Variant } \\
\end{array}$ \\
\hline $\begin{array}{l}\text { Grateful } \\
\text { Animals }\end{array}$ & $\begin{array}{l}\text { "... the rescue from the pit. A traveler saves a monkey, } \\
\text { a snake, a tiger and a jeweler from a pit. The monkey } \\
\text { gives him a fruit, the tiger a necklace of the princess he } \\
\text { has killed. The jeweler accuses the rescuer before the } \\
\text { king. The serpent saves him." (Uther, 2004) (ATU-160) } \\
\text { "... the violinist falls into the wolf's hole together with } \\
\text { the wolf. He plays to them and in the morning, he helps } \\
\text { the bear to get out; the bear then saves him, leaving the } \\
\text { wolf that had hindered the violinist from getting out. } \\
\text { Cf. Lativan." (Uther, 2004) (ATU-160 A) }\end{array}$ & $\begin{array}{l}\text { A Snake, a frog, and a parrot are rescued by the } \\
\text { traveler from the river. The snake provides the } \\
\text { rescuer a magical conch and the rescuer fulfills his } \\
\text { wish by constructing a palace through it; the } \\
\text { rescuer's wife is cheated by an old woman and the } \\
\text { conch is lost but the parrot and the frog help him } \\
\text { find his wife through the conch. The rescuer } \\
\text { restores his lost position through the recovered } \\
\text { conch and he gets back both his wife and his lost } \\
\text { property. }\end{array}$ & $160 \mathrm{~B}$ \\
\hline $\begin{array}{l}\text { Faithful } \\
\text { Animals } \\
\text { Rashly } \\
\text { Killed }\end{array}$ & $\begin{array}{l}\text { "... dog has saved child from serpent. Father sees } \\
\text { bloody mouth, thinks the dog has eaten the child, and } \\
\text { kills the dog. (Sometimes told of mongoose)." Uther, } \\
\text { 2004) (ATU-178) } \\
\text { "A poor man leaves his dog with a wealthy man as } \\
\text { security for a large loan. The dog shows the wealthy } \\
\text { man where thieves had hidden goods and drives off } \\
\text { thieves when they come to ransack the house. The } \\
\text { grateful wealthy man sends the..." (Uther, 2004) } \\
\text { (ATU-178 A) }\end{array}$ & $\begin{array}{l}\text { A king frees a parrot on the condition of providing } \\
\text { him a fruit which can make the king a young man } \\
\text { again. The king guided by the premier tests it on a } \\
\text { dog and the dog dies. The king curses the parrot } \\
\text { and the parrot dies. On the grave of parrot, a plant } \\
\text { grows which is named the killing plant; however, } \\
\text { once an old couple after a fight tries to commit } \\
\text { suicide by eating leaves of killing plant. But they } \\
\text { become young indeed. The king realizes his } \\
\text { mistakes and mourns the death of the parrot. }\end{array}$ & $178 \mathrm{C}$ \\
\hline $\begin{array}{l}\text { WAY OF THE } \\
\text { WORLD }\end{array}$ & $\begin{array}{l}\text { "A man rescues a serpent (or a bear), who in return } \\
\text { seeks to kill the rescuer. Fox, as a judge advises the } \\
\text { man to put the serpent back into captivity" (Uther, } \\
2004) \text { (ATU-155) }\end{array}$ & $\begin{array}{l}\text { The sparrow saves the she-mouse from a series of } \\
\text { mishaps on the way. But the she-mouse comes } \\
\text { with a lot of lame excuses instead of being grateful } \\
\text { to the sparrow. So, she separates her way. }\end{array}$ & $155 \mathrm{~A}$ \\
\hline $\begin{array}{l}\text { THE UNJUST } \\
\text { PARTNERS }\end{array}$ & $\begin{array}{l}\text { "In the field and in the stable. The bear works: the idle } \\
\text { fox cheats the bear." Uther, 2004) (ATU-09) } \\
\text { "The fox pretends to hold up the roof so that it will not } \\
\text { fall on the bear's head." (Uther, 2004) (ATU-09A) } \\
\text { "While sharing the corn planted together, the fox takes } \\
\text { the corn and the bear the chaff. The fox claims the } \\
\text { difference in sound is because his share got moist." } \\
\text { (Uther, 2004) (ATU-09B) } \\
\text { "In the dinner the fox claims to have light porridge } \\
\text { (Uther, 2004)." (ATU-09C) }\end{array}$ & $\begin{array}{l}\text { A crow and a myna decide together to grow a crop } \\
\text { of wheat. They acquire a patch of land and start } \\
\text { working together. They dig a well. The crow's } \\
\text { beak is broken while digging the well. He goes } \\
\text { away to repair his beak and does not return. The } \\
\text { myna calls him back many times. The myna digs } \\
\text { the well herself but the crow does not appear at the } \\
\text { scene. She keeps making calls at different stages of } \\
\text { growing wheat crop: watering, harvesting and } \\
\text { threshing. The crow returns at the site after } \\
\text { threshing and claims all grains of wheat. The crow } \\
\text { flies away while leaving the myna. }\end{array}$ & 09D \\
\hline $\begin{array}{l}\text { The Crocodile } \\
\text { Carries The } \\
\text { Jackal }\end{array}$ & $\begin{array}{l}\text { "The jackal, who wants to eat fruit or carrion on the } \\
\text { other bank, persuades a crocodile to carry him across } \\
\text { the river by saying he will find a bride for the } \\
\text { crocodile. He makes a dummy and, safe back on shoe, } \\
\text { sends the crocodile to that." } \\
\text { (Uther, 2004) }\end{array}$ & $\begin{array}{l}\text { A jackal informs a she-camel of a water-melon's } \\
\text { field across a river. The jackal requests the } \\
\text { she-camel to cross the river on her hump. They } \\
\text { cross the river and reach the water-melon's field. } \\
\text { The jackal just after filling its tummy starts } \\
\text { howling in accordance with his nature. People } \\
\text { gather there and beat the she-camel out of the field. } \\
\text { At this, the jackal sneaks away. On their return, the } \\
\text { she-camel sits amid the river. The jackal cries in } \\
\text { danger of drowning. The she-camel justifies her } \\
\text { act in accordance with her nature. The jackal starts } \\
\text { drowning and a washer man saves him. }\end{array}$ & 58 \\
\hline $\begin{array}{l}\text { The Bird As A } \\
\text { Helper }\end{array}$ & $\begin{array}{l}\text { "A youth shoots a raven: saving the princess from a sea } \\
\text { monster. With a feather of raven, the youth gets magic } \\
\text { objects and treasure from the raven's sister." (Uther, } \\
\text { 2004) }\end{array}$ & $\begin{array}{l}\text { A king goes out for hunting but fails to catch any } \\
\text { prey. Being tired, he relaxes under a tree. A parrot } \\
\text { meets the king. He tells him about the beauty of } \\
\text { fairy land and fairies. The king meets a beautiful } \\
\text { princess imprisoned by a giant. The giant appears. } \\
\text { The giant tells her that his life is in the parrot } \\
\text { locked in a small box. On listening this, the king } \\
\text { requests the parrot to help him find the box. They } \\
\text { free the queen and the king marries the beautiful } \\
\text { princess. }\end{array}$ & 553 \\
\hline $\begin{array}{l}\text { The Old } \\
\text { Woman And } \\
\text { Her Pig; Crow } \\
\text { Must Wash His } \\
\text { Bill; Mouse } \\
\text { Eats Old }\end{array}$ & $\begin{array}{l}\text { "Her pig will not jump over the stile so that she can go } \\
\text { home. She appeals in vain for help until the cow gives } \\
\text { her milk. The final formula is: cow give milk for the } \\
\text { cat, cat kill rat, rat gnaw rope, rope hang butcher, } \\
\text { butcher kills ox, or ox drink water." (Uther,2004) }\end{array}$ & $\begin{array}{l}\text { An old woman's popcorn is dropped and picked by } \\
\text { a crow. She requests the crow to give back her } \\
\text { popcorn. The crow denies returning the popcorn. } \\
\text { She goes to the tree to make the crow fly away. } \\
\text { The tree refuses to do so. She goes to the carpenter } \\
\text { to cut tree, to the king to exile the carpenter and to }\end{array}$ & 2030c \\
\hline
\end{tabular}




$\begin{array}{ll}\text { Couple's } & \text { "Asks water; water must have horn from stag, who } \\ \text { Cheese; } & \text { must first have milk from cow, etc." (Uther, 2004) } \\ & \text { "Cat kills mouse for eating cheese. Dog kills cat for } \\ & \text { eating mouse." (Uther, 2004) }\end{array}$

The Girl's
Riddling
Answers;
What the
Geese/ Cock
Say

Lucky Shot; Shot Splits Tree Limbs

\begin{abstract}
"The full moon and the thirtieth of the month. Prince sends servant to clever girl with a round tart, thirty cakes, and a capon, and asks her if it is full moon and the thirtieth of the month and if the cock has cried in the evening. She replies that ..," (Uther, 2004) "She explains the enigmatic statements and actions encountered on the way; succeeds in a contest in repartee and in performing impossible tasks." (Uther, 2004)
\end{abstract}

"Discharge of gun kills the heath-cock, which falls on the sprouts on the tree, which kills the bear, etc." (Uther,2004)

"Bird's feet caught in the crack, and other lucky accidents bring much game." (Uther, 2004) the queen to wage her influence with the king. She goes to the rat to nibble the queen's dress, to the dog to eat the cat, to the bamboo tree to beat the $\mathrm{dog}$, to the fire to burn the bamboo trees, to the water to quench fire, to the elephant to drink water and finally to the mosquito to enter into the elephant's ear. The chain is broken by the mosquito. The crow returns the old woman's popcorn and she moves away.

A clever girl of a premier helps her father in solving a king's riddle. The riddle is $:<<$ what the geese say while flying $>>$. She says: $<<$ they say if we alight none can make us fly and if we fly none can make us alight. $>>$ The king marries her and keeps her locked in a palace situated on the bank of a sea. One day a merchant's son passes by the palace. She asks him to dig a tunnel to enter the palace. The merchant's son digs a tunnel. The next day, the king finds a letter with the following sentence on it: < if we alight none can make us fly and if we fly none can make us alight.>

A merchant has an idle son. The merchant dies one day. His mother asks him many times to do business. He tries his luck. The old dips a bucket into a river against a diamond. People get treasure. The merchant's son tries his luck. At the third time, he gets three animals: a snake, a mouse and a parrot instead of treasure. The snake gives him a magic stone. He leaves the snake and brings the parrot and the mouse at home. The merchant's son constructs his palace with gold. Even, the hair of his wife is made golden by the touch of magic stone. One day, his wife's hair is traced by a king of the next state. He shows his desire to wed a woman with golden hair. A clever old woman helps the king trace the woman. She in the absence of her husband traps her. In the meantime, the merchant's son comes back. He frees the parrot to trace his wife and magic stone. The parrot and mouse help the merchant's son in finding both the merchant's wife and magic stone.

The researcher compared Saraiki folktales with the ATU animal tales. The plot of the ATU 160 has five following characters: a snake, a monkey, a traveller and a jeweler and in the plot of the ATU 160 A, there are two characters: a wolf and a violinist. There are four characters in the Saraiki folktale: a snake, a frog, a parrot and a traveller. Among them, the two characters are the same in both the folktales i.e. the Saraiki folktales and the ATU folktales 160 and $160 \mathrm{~A}$. In both the folktales, the rescuer is the same, the traveller and with the exception of the one rescued all other are different but they all are animals and the rescuer is the human character. The folktale 160 ATU is quite close to the Saraiki folktale recorded from the Saraiki region with the same sort of animal (snake) which is present in both the types of folktales. The numbers of characters in the ATU folktales 178, $178 \mathrm{~A}, 178 \mathrm{~B}$ are three namely, a dog, a father and a child and the numbers of characters in the Saraiki folktales are five: a king, a parrot, a premier, a dog and an old couple. In the Saraiki and the ATU folktale both the characters, the king and the father, behave similarly as they kill their faithful animals i.e. the parrot and the dog. In the ATU folktale 155, there are three and in the Saraiki folktale two characters respectively. The plots of the above stated folktales exhibit the sameness with the differences of the characters as in the Saraiki folktale, 'Sparrow and She-Mouse' both the rescuer and the recued are animals. In the above stated ATU serpent is evil by nature and in the Saraiki folktale the she-mouse is considered an evil natured character. While in the ATU plot, the fox and in the Saraiki folktale the sparrow show positive dispositions of their characters. The Saraiki folktale, 'A Crow and Myna' has sameness in plot with the plots of internationally recorded ATU folktales 09, 09 A, 09 B, and 09 C. In the Saraiki folktale, a crow and a myna are the partners and in the ATU folktales, a fox and a bear are the partners. In the plots of the Saraiki folktale and ATU folktales, the tricksters: a crow and a fox respectively do nothing. The tricksters cheat the protagonists of Saraiki and ATU folktales: a myna and a bear. The tricksters claim more than their shares through deception and trickery. The characters in the 
above-mentioned Saraiki and ATU folktales have the same characteristics and dispositions.

\section{Conclusion}

The ATU analysis of the folktales revealed many significant aspects of the Saraiki folktales. The Saraiki animal tales were found pretty similar to the plots recorded in the ATU system of classification. The differences of characters/dramatis personae were however noticed along with the differences in the sequences of plots. The salient aspects of the Saraiki animal tales have been found through the ATU system of classification. First, in many cases, the crux, themes, plots and the titles of both the tales in the ATU system of classification and the Saraiki animal tales were the same. Second, the numbers of actors/agents/characters/dramatis personae were more/same in the Saraiki folktales apart from the few instances of the Saraiki folktales where the numbers of characters were less than the number of characters in the ATU System of classification. Third, in certain folktales the titles and characters were different but there was sameness in the plots of both the folktales in the ATU System of Classification and the Saraiki folktales. Fourth, the numbers of events in the Saraiki folktales were also more/same than the numbers of events in the ATU system of classification. These deviations from the Aarne-Thompson-Uther System of Classification were due to the occurrence of these folktales in the far flung areas/region. The folktales might have travelled either ways across thousands of miles but the plots of them still showed sameness among them.

Many folktales of the Saraiki language and region have the sameness of titles and of the plots for example the ATU variant 160, and the Saraiki folktale titled 'Grateful Animals: Ungrateful Man' and 'Grateful Animals: Snake, Frog, Parrot and Traveller'; the ATU variant 178 and the Saraiki folktale have the sameness in titles such as, 'Faithful Animals Rashly Killed' and 'The faithful Parrot Blindly Killed (Cursed) respectively. The ATU variant 09 and the Saraiki folktale have the sameness of titles and plots such as, 'The Unjust Partners' and, 'The Unjust Partners-Crow and Myna' respectively. Then there are many folktales where the numbers of characters in the Saraiki folktales are more than their ATU counterparts such as in the Saraiki folktale No. 2 and the ATU variant 178, the numbers of characters are 03 and 05 respectively and in both the instances two types of characters are the humans such as father and the king and the animals such as the dog and the parrot and dog is the common character in both the folktales. The Saraiki folktale and the ATU variant 155 have 02 and 03 numbers of characters in them respectively and with the exception of two human character all other characters are animals such as serpent, sparrow and mouse. The informants of study were not literate enough to study the stories from any other source and the folktales reach them after generation to generation travel. The informants live thousands of miles away from the informants of Western world but the plots of Saraiki animal tales have similarity in all respects as mentioned above in the analysis. This study confirms both the antiquity of Saraiki culture of oral tradition and language.

\section{References}

Aarne, A. (1912). Ubersicht der mitdemVerzeichnis der Marchentypen in den Sammlungen Grrimms, Grundtvigs, Afanasjews, Gonzenbachs und Hahnslibereinstimmenden. Hamina: SuomalaienTiedeakatemia

Akbar, M. (2012). Hafiz Mohammad Shirani Aur Dr. Mahar Abdul Haq: Lisani nizrizaat-taqabali mutaala. Pakistan: Idara Farogh e Adab.

Ashraf, (2011). Allah ApBadshah Hay. [Saraki: Allah is a great king]. Multan:Saraiki Adabi Board

Ayyaz, (2004). Saraiki Wateeray. [Saraiki: Saraiki Tradition] Multan: Saraiki Adbi Board.

Coquin, E. (1886). Contespopulaires de Lorraine. Journal of Folk Narrative, 16(1), 1-26.

Cresswell, J. (2007). Qualitative Inquiry \& Research Design: Choosing among five approaches. London: Sage Publications.

Degh, L. (1972). Folk Narrative. In R, Dorson (Ed.), Folklore and Folk life (2nd ed., pp. 53-83). NY. America: Greenwood Press.

Grierson, G. (1919). Linguistic Survey of India. Calcutta: Superintendent Government Printing.

Haase, D. (Ed.) (2008). The Greenwood Encyclopedia of Folktales and Fairy Tales. USA: Greenwood Press.

Haidar, S. (2009). Mukhtasar Tareekh Zubanu Adab Saraiki. Islamabad, Pakistan: Muqtadara Qaumi Zuban.

Hashmi, R. S., \& Majeed, G. (2014). Saraiki Ethnic Identity: Genesis of conflict with state. Journal of Political Studies, 21(1), 79-101.

Hymes, D (1974). Foundations in Sociolinguistics: An ethnographic perspective. Philadelphia: University of Pennsylvania Press. 
Khadija, A. (2008). Saraiki Dharti De Qissay. [Saraiki: The Folktales of Saraiki Region]. Multan: Saraiki Adbi Board.

Killeen, J. (2007). Fairy Tales of Oscar Wilde Surrey. America: Ashgate Publishing

Kincaid, C. A. (1914). Deccan Nursery Tales. NY, America: Macmillan and Co., Ltd

Krohn, K, (1971). Folklore Methodology. Texas, America: Austin University of Texas Press.

Lewis, J., \& Ritchie, J. (2003). Qualitative Research Practice: A Guide for Social Science Students and Researchers. London: Sage Publication.

Mughal, S. (2004). Pachira. Multan, Pakistan: Saraiki Adbi Board.

Naich, H. (2010) Cholistani Kahania. [Saraiki: Cholistani Folktales] Multan: Saraiki Adbi Board.

Quintus, A. J. (1991). Christ, Christianity, and Oscar Wilde. Texas Studies in Literature and Language, 33(4), $514-527$

Robson, C. (2002). Real World Research: A Research for Social Scientists and Practioner Researchers. Oxford: Blackwell.

Shackle, C. (1976). The Saraiki Language of Central Pakistan. London: School of Oriental and African Studies, University of London.

Shah, A. (2008). Sojhal Qissay. [Saraiki: Enlightening Folktales]. Multan: Saraiki Adbi Board.

Snider, C. (2009). On the Loom of Sorrow: Eros and logos in Oscar Wilde fairy tales Retrieved from www.csulb.edu/ csnider/wilde.fairy.tales/html

Stephen, et al. (2005). Living Folklore. Logan Utah: Utah State University Press.

Summers, C. J. (1990). GAY GICTIONS: Wilde to Stonewall. New York: OUP.

Swales, J. (1990). Genre Analysis. Cambridge: Cambridge University Press

Thompson, S. (1946). The folktale. New York: Dryden.

Tolken, B. (1996). The dynamics of folklore (Rev. Ed). Logan, Utah: Utah State University Press. https://doi.org/10.2307/j.ctt46nrng

Uther, H. (Ed.) (2004). The Types of International Folktales: A classification and bibliography based on the system of Anti Aarne and Stith Thompson (pp. 1-3). Helsinki: Suomalainen Tiedeakatemia.

\section{Copyrights}

Copyright for this article is retained by the author, with first publication rights granted to the journal.

This is an open-access article distributed under the terms and conditions of the Creative Commons Attribution license (http://creativecommons.org/licenses/by/4.0/). 